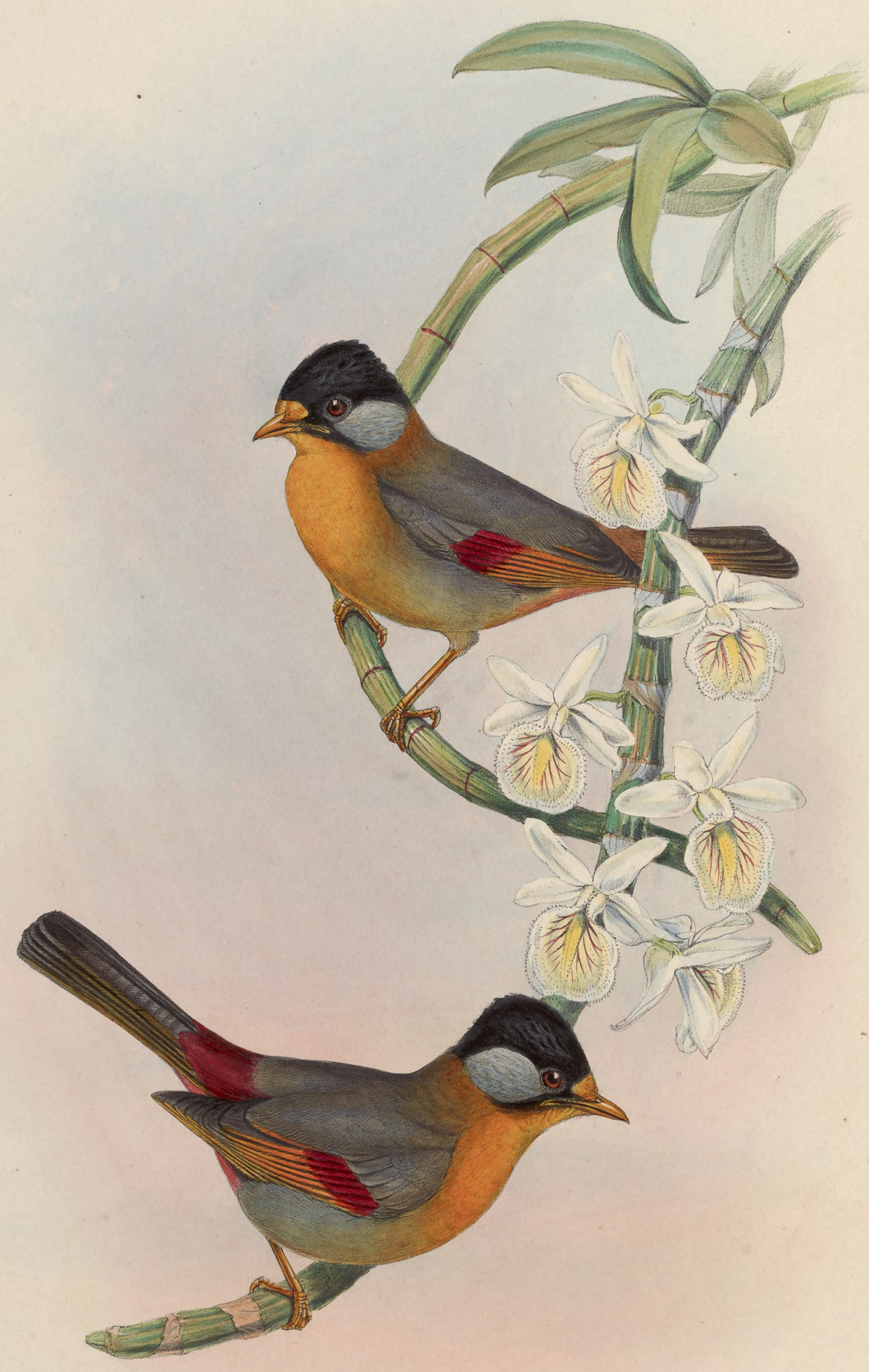

IEIOTIIRIX ARGENTAURIS. 


\section{LEIOTHRIX ARGENTAURIS.}

\section{Silver-eared Leiothrix.}

Mesia argentauris, Hodgs. Ind. Rev., vol. ii. 1838, p. 88.-Gray, List of Spec. and Draw. of Mamm. and Birds pres. to Brit. Mus. by B. H. Hodgson, Esq., p. 94.

Leiothrix argentauris, Gray and Mitch. Gen. of Birds, vol. i. p. 269.-Blyth, Cat. of Birds in Mus. Asiat. Soc. Calcutta, p. 99.-Id. Journ. Asiat. Soc. Calcutta, vol. xxiv. p. 279.-Bonap. Consp. Gen. Av., tom. i. p. 332.-Horsf. and Moore, Cat. of Birds in Mus. East Ind. Comp., vol. i. p. 365.

Philocalyx argentauris, Hodgs. Journ. Asiat. Soc. Beng., vol. x. p. 29

Fringilloparus argentauris, Hodgs. Journ. Asiat. Soc. Beng., vol. xiii. p. 935.

Fringilloparus (Mesia) argentauris, Hodgs. in Gray's Zool. Misc., 1844, p. 84.

THIs bird has so many characters in common with the type of the genus Leiothrix ( $L$. huteus), that I am inclined to associate it with that bird, rather than to adopt the generic term of Mesia, proposed for it by Mr. Hodgson. Both L. luteus and L. argentauris have very truncate tails : the outer feathers of the former, it is true, turn outwards in a somewhat singular manner, reminding one of Lyrurus among the Grouse, but I regard this difference as specific rather than as generic; in the form of their bills, legs, and wings, they are very similar. The native locality of this fine bird is the southern face of the great Himalayas ; and it is in all probability universally distributed over every district, from Nepaul on the east to Afghanistan on the west. My own specimens are from the former country; but Mr. Moore, of the India Museum, states that a specimen contained in that collection was obtained in Afghanistan by Mr. Griffith. Like most of the Leiotrichine birds, a great similarity exists in the colouring of the two sexes of this species; but some individuals are much less brightly coloured than others : in all probability these are females.

The few members known of the genus Leiothrix are more robust in form than those of Siva; they have also more hooked and stouter bills.

Forehead, bill, throat, and chest fine orange ; ear-coverts silvery grey, remainder of the head black; nape orange-brown; back, scapularies, and wings dark grey; the greater coverts rich, deep blood-red, and the primaries margined with orange-red; upper and under tail-coverts deep blood-red; tail dark olive, margined externally with dull orange; under surface grey; centre of the abdomen orange-buff; feet reddish fleshcolour; irides brown.

The figures are of the natural size. The plant is the Dendrobium cretaceum. 


\section{$2 \mathrm{BHL}$ Biodiversity Heritage Library}

Gould, John. 1862. "Silver-eared Leiothrix, Leiothrix argentauris [PI. 16]." The Birds of Asia 4(XIV), -. https://doi.org/10.5962/p.323383.

View This Item Online: https://www.biodiversitylibrary.org/item/120503

DOI: https://doi.org/10.5962/p.323383

Permalink: https://www.biodiversitylibrary.org/partpdf/323383

\section{Holding Institution}

Smithsonian Libraries

\section{Sponsored by}

Smithsonian Institution Libraries

\section{Copyright \& Reuse}

Copyright Status: Not in copyright

This document was created from content at the Biodiversity Heritage Library, the world's largest open access digital library for biodiversity literature and archives. Visit BHL at https://www.biodiversitylibrary.org. 